\title{
Marc Bayard, Feinte baroque. Iconographie et esthétique de la variété au XVII siècle
}

\section{Laura Rescia}

\section{(2) OpenEdition}

\section{Journals}

\section{Edizione digitale}

URL: http://journals.openedition.org/studifrancesi/5599

DOI: 10.4000/studifrancesi.5599

ISSN: 2427-5856

\section{Editore}

Rosenberg \& Sellier

\section{Edizione cartacea}

Data di pubblicazione: 1 septembre 2011

Paginazione: 400-401

ISSN: 0039-2944

\section{Notizia bibliografica digitale}

Laura Rescia, «Marc Bayard, Feinte baroque. Iconographie et esthétique de la variété au xvı" siècle», Studi Francesi [Online], 164 (LV | II) | 2011, online dal 30 novembre 2015, consultato il 13 janvier 2021. URL: http://journals.openedition.org/studifrancesi/5599; DOI: https://doi.org/10.4000/studifrancesi.5599

Questo documento è stato generato automaticamente il 13 janvier 2021.

\section{(a) $\odot \Theta$}

Studi Francesi è distribuita con Licenza Creative Commons Attribuzione - Non commerciale - Non opere derivate 4.0 Internazionale. 


\title{
Marc Bayard, Feinte baroque. Iconographie et esthétique de la variété au XVII siècle
}

\author{
Laura Rescia
}

\section{NOTIZIA}

MARC BAYARD, Feinte baroque. Iconographie et esthétique de la variété au XVII siècle, Collection d'histoire de l'art, Académie de France à Rome - Ville Médicis, Somogy éditions d'art, Paris, 2010, 256 pp.

1 Il volume riprende, in versione riveduta e arricchita, una tesi di storia dell'arte diretta da Yves Hersant, centrata sullo studio dei quarantasette schizzi dei Mémoires di Mahelot, realizzati per l'Hôtel de Bourgogne e recentemente attribuiti a Georges Buffequin. I disegni si riferiscono alle scenografie di rappresentazioni teatrali degli anni '30-40, proprio all'apice della querelle du Cid e del dibattito tra regolari e irregolari.

2 Se i Mémoires sono da tempo oggetto di studio da parte degli storici del teatro, essi vengono qui per la prima volta presi in esame in quanto oggetto artistico, e studiati in una doppia prospettiva. Sono infatti indagate sia la presenza di forme e motivi che l'uso degli spazi scenici: gli elementi estetici e tecnici delle scenografie, analizzati con la competenza dello storico dell'arte, vengono interpretati nel loro valore storico, filosofico, ideologico, e la scena decifrata come indizio e testimonianza del divenire dell'immaginario culturale e poetico del Seicento francese. Grazie allo studio delle scenografie è possibile verificare la consonanza tra cambiamenti estetici e poetici: $i$ risultati dell'analisi iconologica e dell'uso dello spazio vengono infatti, nella seconda parte del volume, raffrontati con le tensioni che attraversano le poetiche teatrali negli stessi anni, per metterne in luce le tendenze evolutive. Ci si concentra in particolare sullo studio del Discours à Cliton sur les Observations du Cid, assunto a manifesto dell'estetica della varietas, che qui non si esita a definire barocca. 
3 Il volume si avvale di una grafica curata ed elegante: i materiali iconografici vengono riprodotti, come pure la lista delle scenografie e degli accessori necessari per la messa in scena, arricchiti con commenti critici e notizie sulle opere e gli autori. Viene altresì allegato il testo del Discours à Cliton, sulla base sull'edizione fornita da J.M. Civardi nel 2004, qui modernizzato. 